\title{
Poly(methyl methacrylate) reinforced poly(vinylidene fluoride) composites electrospun nanofibrous polymer electrolytes as potential separator for lithium ion batteries
}

\author{
Yogita P. Mahant ${ }^{1} \cdot$ Subhash B. Kondawar ${ }^{1} \cdot$ Deoram V. Nandanwar $^{2} \cdot$ Pankaj Koinkar $^{3}$
}

Received: 12 January 2018 / Accepted: 21 March 2018 / Published online: 27 March 2018

(c) The Author(s) 2018

\begin{abstract}
Fabrication of nanofibrous polymer electrolyte membranes of poly(vinylidene fluoride) (PVdF) and poly(methyl methacrylate) (PMMA) in different proportion (PVdF:PMMA = 100:0, 80:20 and 50:50) by electrospinning is reported to investigate the influence of PMMA on lithium ion battery performance of PVdF membrane as separator. As-fabricated polymer electrospun nanofibrous membranes were characterized by SEM, FTIR, XRD, TGA and DSC for morphology, structure, crystallinity and thermal stability. PVdF-PMMA (50:50) polymer electrolyte membrane showed ionic conductivity $0.15 \mathrm{~S} /$ $\mathrm{cm}$ and electrolyte uptake $290 \%$ at room temperature. After 50 cycles, the discharge capacity $140 \mathrm{mAh} / \mathrm{g}$ of Li/PE/LiFePO cells with PVdF-PMMA (50:50) as polymer electrolyte (PE) membrane was found to be retained around 93.3\%. The electrolyte uptake, ionic conductivity, and discharge capacity retention were improved by optimizing the proportion of PMMA in PVdF. Nanofibrous PVdF-PMMA (50:50) polymer electrolyte membrane was found to be a potential separator for lithium ion batteries.
\end{abstract}

Keywords Poly(vinylidene fluoride) $\cdot$ Poly (methyl methacrylate) $\cdot$ Polymer electrolyte $\cdot$ Electrospinning $\cdot$ Nanofibers Lithium ion batteries

\section{Introduction}

Lithium ion batteries have been improved using polymer nanofibrous electrolyte membrane with its highly porous structure, high electrolyte uptake and ionic conductivity to transport as much as lithium ions through it. Polymer nanofibrous electrolyte membrane provides wide electrochemical operating window and good thermal stability useful to prevent electrolyte leakage and to minimize the firing hazard for high safety of batteries as compared to liquid

Subhash B. Kondawar

sbkondawar@yahoo.co.in

Pankaj Koinkar

koinkar@tokushima-u.ac.jp

1 Department of Physics, Rashtrasant Tukadoji Maharaj Nagpur University, Nagpur 440033, India

2 Department of Physics, Shri Mathuradas Mohata College of Science, Nagpur 440023, India

3 Department of Optical Science, Tokushima University, Tokushima 7708506, Japan polymer electrolyte [1-6]. Poly(ethylene oxide) (PEO), polyacrylonitrile (PAN), poly (methyl methacrylate) (PMMA), poly(vinylidene fluoride) (PVDF), poly(vinyl alcohol) (PVA) and poly(vinylidene fluoride-co-hexafluoropropylene) (PVDF-HFP) have been studied as host polymer for fabricating nanofibrous polymer electrolyte membrane [7-16]. Among these polymers, poly(vinylidene fluoride) (PVdF) has been mostly used as a semi-crystalline polymer with excellent film-forming ability, high dielectric constant and thermal stability [17]. But the crystalline domains of PVdF restrict the penetration of liquid electrolytes and the movement of lithium ions from between the electrodes during charging and discharging which show low ionic conductivity. Therefore, researchers in this field are more engaged to prepare polymer electrolyte membranes by blending or forming composites using different polymers or metal oxides to increase ionic conductivity, electrolyte uptake, and electrochemical stability than that of pure polymer electrolytes [18-22]. Li et al. prepared PVDF/PMMA membrane by anchoring PMMA to multiporous PVDF surface via electron beam preirradiation grafting technique and showed ionic conductivity $6.1 \times 10^{-3} \mathrm{~S} / \mathrm{cm} \mathrm{[23]}$. Also, Idris et al. 
(a)

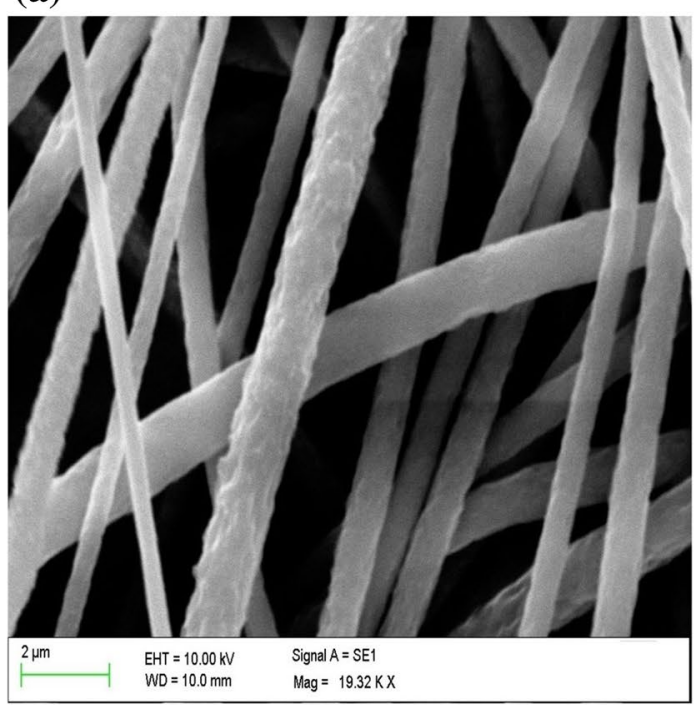

(c)

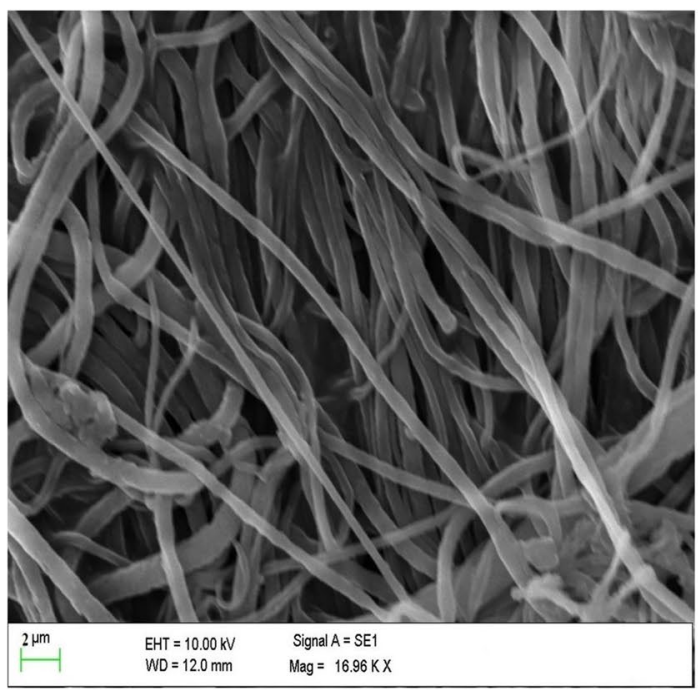

(e)

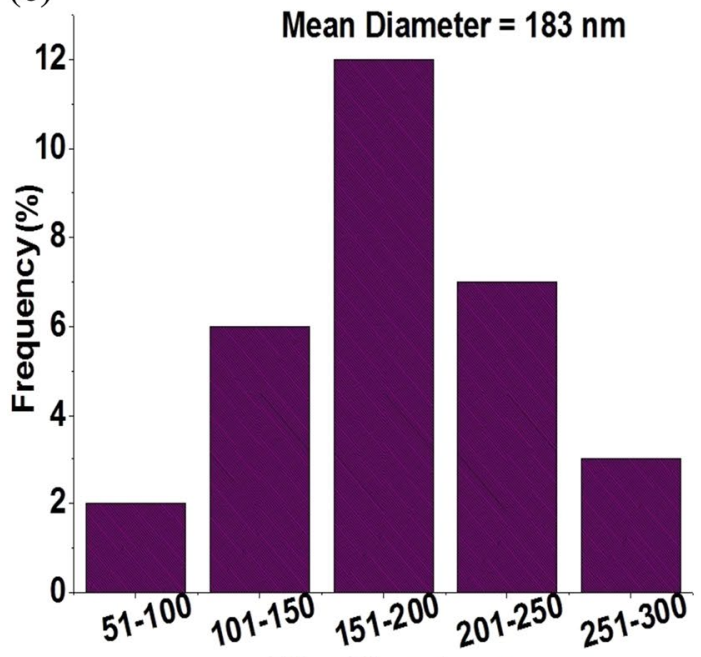

Fiber Diameter $\mathrm{nm}$ (b)

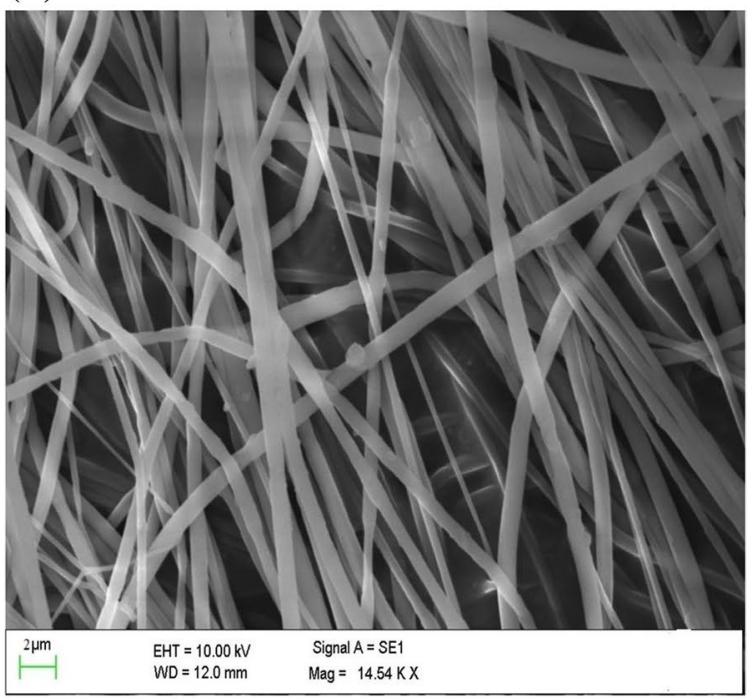

(d)

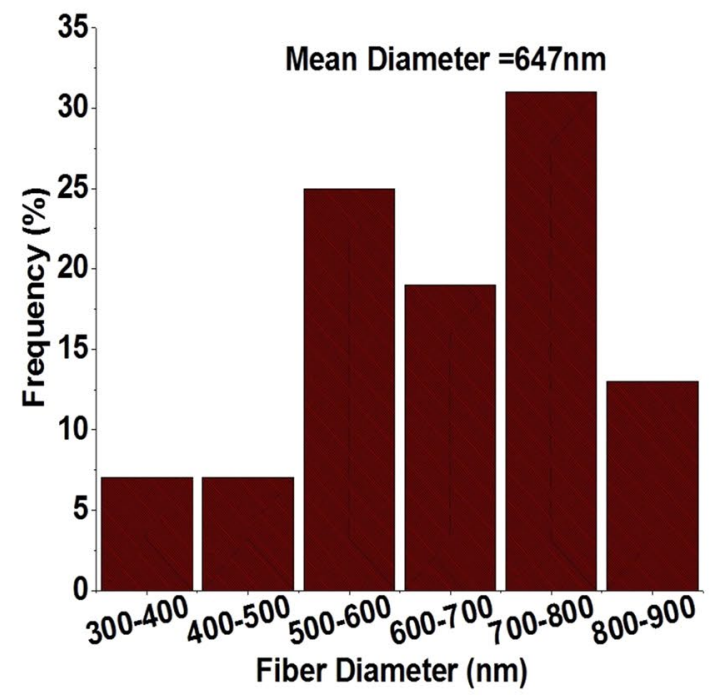

(f)

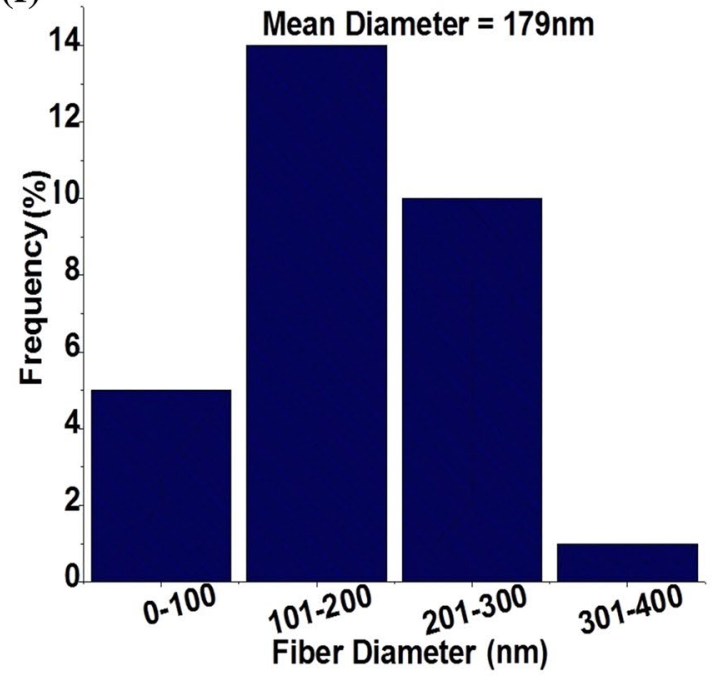


४Fig. 1 a SEM image of electrospun PVdF nanofibrous membrane. b SEM image of electrospun PVdF-PMMA (80:20) nanofibrous membrane. c SEM image of electrospun PVdF-PMMA (50:50) nanofibrous membrane. d Histogram of electrospun PVdF nanofibrous membrane. e Histogram of electrospun PVdF-PMMA (80:20) nanofibrous membrane. f Histogram of electrospun PVdF-PMMA (50:50) nanofibrous membrane

prepared $\mathrm{PVdF} / \mathrm{PMMA}$ microporous membranes using the phase-separation method with increasing percentage of PMMA and showed discharge capacity of $133 \mathrm{mAh} / \mathrm{g}$ [24]. Many different synthesis methods are used to prepare polymer electrolyte membrane by solution casting $[15,20]$, phase inversion [25] and electrospinning [26]. Among them, electrospinning is a simple method for preparation of nanofibrous membranes with high porosity due to tunable fiber diameter controlled by varying applied electric field, distance between syringe needle and grounded collector, polymer solution concentration, and flow rate of viscous polymer solution. Porosity is the size-dependent property; therefore, electrospun nanofibers of blended polymers synthesized by electrospinning possess high porosity which is responsible for increase in electrolyte uptake and high ionic conductivity at room temperature $[27,28]$. Li et al. and Mahant et al. prepared fibrous membranes of poly(vinylidene fluoride)/ poly(methyl methacrylate) (PVdF/PMMA) by electrospinning method and showed ionic conductivity $3.5 \times 10^{-3}$ and $2.95 \times 10^{-3} \mathrm{~S} / \mathrm{cm}$, respectively $[29,30]$. Therefore, efforts have been made to optimize the composition of $\mathrm{PVdF}$ and PMMA to fabricate their composites nanofibrous membrane by electrospinning so as to increase the ionic conductivity.

In this work, the fabrication of polymer nanofibrous electrolyte membranes of PVdF-PMMA composites in different proportion (PVdF:PMMA = 100:0, 80:20 and 50:50) by electrospinning is reported to investigate the influence of PMMA on lithium ion battery performance. The effect of concentration of PMMA in composites on morphology, ionic conductivity, porosity and discharge capacity retention for lithium ion battery separator is studied and systematically compared.

\section{Experimental}

\section{Preparation of PVdF-PMMA composites nanofibrous polymer electrolytes}

PVdF-PMMA composites were prepared with varying weight ratio of PMMA in PVdF. The total polymer concentration was fixed at $15 \mathrm{wt} \%$. PVdF-PMMA composites nanofibrous membranes in different proportion of $\mathrm{PVdF}$ and PMMA were prepared by electrospinning. In a typical procedure for the preparation of PVdF-PMMA (50:50) nanofibrous membrane, 15\% PVdF-PMMA (5:5, w/w) was dissolved in a mixed solvent $\mathrm{N}, \mathrm{N}$-dimethylformamide (DMF)/tetrahydrofuran (THF) (7:3, V/V) and magnetically stirred to form a homogeneous solution and then transferred the mixed polymer solution to disposable syringe for electrospinning to get continuous nanofibers. During electrospinning, computer controlled flow rate $0.6 \mathrm{ml} / \mathrm{h}$, electric field $20 \mathrm{kV}$ and distance $18 \mathrm{~cm}$ between the syringe needle and grounded collector (aluminum foil) were maintained. The nanofibrous membrane on the collector plate was dried under vacuum at $70{ }^{\circ} \mathrm{C}$ for $12 \mathrm{~h}$ and then separated from the foil for preparation of polymer electrolyte. In the similar way, PVdF-PMMA (50:50) and PVdF-PMMA (100:00) abbreviated as pure PVdF have been prepared by electrospinning with the same operating conditions. PVdF-PMMA nanofibrous polymer electrolytes were prepared by immersing the electrospun nanofibrous membranes in $1 \mathrm{M} \mathrm{LiPF}_{6}$ (lithium hexaflurophosphate) in EC:DMC $(1: 1 \mathrm{v} / \mathrm{v})$ (ethylene carbonate and dimethyl carbonate) solution at room temperature in a glove box under nitrogen atmosphere.

\section{Characterizations}

The surface morphology of electrospun nanofibrous membranes was investigated by scanning electron microscope (CARL ZEISS EVO-18). Fourier transform infrared (FTIR) spectra of electrospun nanofibrous membranes were obtained on $\alpha$-Bruker model. X-ray diffraction (XRD) patterns of electrospun nanofibrous membranes were on Rigaku Miniflex II Desktop X-ray diffractometer. The crystallinity of electrospun nanofibrous membranes was obtained using differential scanning calorimetry (DSC) (Mettler Toleno DSC 822 e) with heating rate $10^{\circ} \mathrm{C}$ per min under $\mathrm{N}_{2}$ atmosphere. Thermogravimetric analysis (TGA) was done by Perkin Elmer STA 6000 at the heating rate $10{ }^{\circ} \mathrm{C} \mathrm{min}^{-1}$ from room temperature to $700{ }^{\circ} \mathrm{C}$ under $\mathrm{N}_{2}$ atmosphere. Porosity of electrospun nanofibrous membranes was calculated by weighing membrane before and after absorbing $n$-butanol and knowing the density of $n$-butanol. The electrolyte uptake of polymer electrolyte membranes was calculated by soaking the membrane in lithium hexaflurophosphate $\left(\mathrm{LiPF}_{6}\right)$, ethylene carbonate (EC) and dimethyl carbonate (DMC) solution. The ionic conductivity $(\sigma)$ of polymer electrolyte membranes was determined through an ionic conductivity cell, by sandwiching a given polymer electrolyte membrane between two stainless steel blocking electrodes (SS/polymer electrolyte membrane/SS, SS: stainless steel) using Zahner Zennium Electrochemical Analyzer at room temperature in frequency range between $10 \mathrm{mHz}$ and $100 \mathrm{kHz}$ with $\mathrm{AC}$ amplitude of $10 \mathrm{mV}$. 


\section{Results and discussion}

Figure 1 shows SEM images and histograms of electrospun (a) PVdF, (b) PVdF/PMMA (80-20), and (c) PVdF-PMMA (50-50) nanofibrous membranes. It can be seen from SEM images that the average fiber diameter decreases with increasing PMMA percentage from 0 to $50 \%$ in the composites. The average fiber diameter of PVdF, PVdF-PMMA (80:20) and PVdF-PMMA (50:50) is found to be 647, 183 and $179 \mathrm{~nm}$, as shown in histograms Fig. 1d-f, respectively. This unique porous structure is beneficial for the electrolyte to penetrate and retain electrolyte effectively, and it facilitates an electrolyte to diffuse smoothly into the cell assembly.

Figure 2 shows the FTIR spectra of electrospun PVdF, PVdF-PMMA (80-20) and PVdF-PMMA (50-50) nanofibrous membranes. It is observed from the figure that for pure PVdF, the characteristic bands are appeared at 1727, 1401, $1077,1005,884,690$ and $621 \mathrm{~cm}^{-1}$. The band at $1727 \mathrm{~cm}^{-1}$

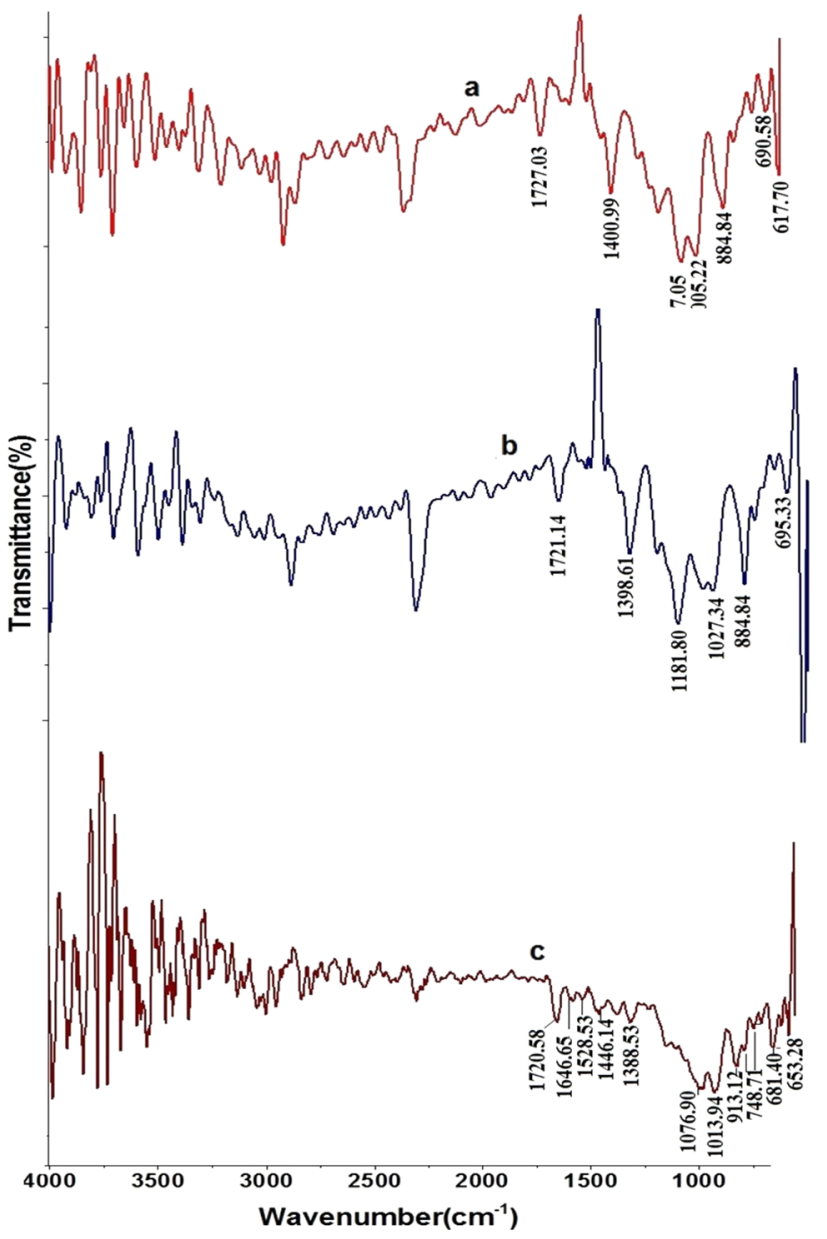

Fig. 2 FTIR spectra of a PVdF, b PVdF-PMMA (80:20), and c PVdF-PMMA (50:50) nanofibrous membranes assigned to stretching vibration of $\mathrm{C}=\mathrm{C}$. The band at $1401 \mathrm{~cm}^{-1}$ is related to stretching vibration of $\mathrm{CF}_{2}$ group. The bands appearing at 1077 and $1005 \mathrm{~cm}^{-1}$ are appeared due to scissoring vibration of $\mathrm{CF}_{2}$ group and stretching vibration of $\mathrm{CH}$ group, respectively. A band at $884 \mathrm{~cm}^{-1}$ which shows the characteristic peak of vinylidene group of $\mathrm{PVdF}$ is assigned to C-F stretching. The bands at 690 and $621 \mathrm{~cm}^{-1}$ are due to crystalline phase of PVdF and indicate out of plane $\mathrm{C}-\mathrm{H}$ bending and bending vibration of $\mathrm{CF}_{2}$. The characteristic bands for PVdF-PMMA (80:20) are appeared at $1721,1398,1181,1027,884,695$ and $621 \mathrm{~cm}^{-1}$. The band at $1721 \mathrm{~cm}^{-1}$ is identified as $\mathrm{C}=\mathrm{O}$ stretching vibration in the pendant group $\left(-\mathrm{COOCH}_{3}\right)$ of PMMA. The characteristic peaks at 1398 and $884 \mathrm{~cm}^{-1}$ are due to $\mathrm{C}-\mathrm{H}$ bending vibration and $-\mathrm{CH}_{2}-$ stretching vibration [31]. It is observed that the intensity and peak position are slightly shifted due to blending of PMMA. These changes clearly indicate the miscibility of PVdF and PMMA. For PVdF-PMMA (50:50), it is found that new bands at 1446 and $1528 \mathrm{~cm}^{-1}$ are appeared. The band at $1446 \mathrm{~cm}^{-1}$ corresponds to $\mathrm{CH}_{2}$ wagging deformation of pure PVdF membrane. It can be seen that intensity of this peak increases with the addition of PMMA. The peak corresponding to $1734 \mathrm{~cm}^{-1}$ in the PVDF/PMMA blend membrane is due to the carbonyl $(\mathrm{C}=\mathrm{O})$ group present in PMMA. This result suggests that there is a specific interaction between the carbonyl groups of PMMA and the $\mathrm{CH}_{2}$ groups of PVDF and indicates the formation of a PVDF/ PMMA blend membrane.

$\mathrm{X}$-ray diffraction pattern helps to provide the influence of PMMA on structure of PVdF in the sample. Figure 3 shows the XRD patterns of PVdF, PVdF-PMMA (80-20) and PVdF-PMMA (50-50) nanofibrous membranes. PVdF membrane has sharp peaks at $20.7^{\circ}(110)$ and $26.60^{\circ}(022)$

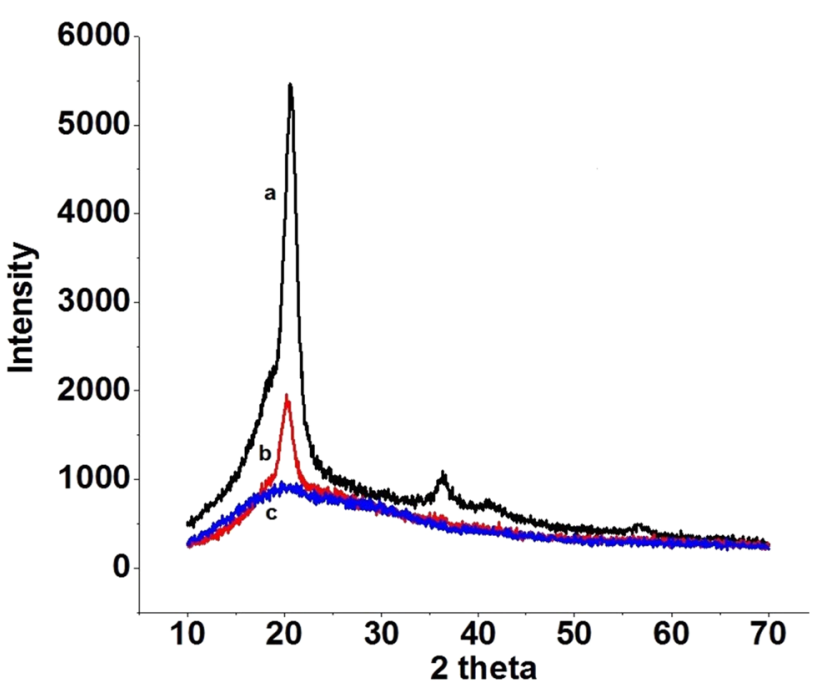

Fig. 3 XRD patterns of a PVdF, b PVdF-PMMA (80:20), and c PVdF-PMMA (50:50) nanofibrous membranes 
corresponding to orthorhombic $\alpha$-phase of PVdF [30]. These peaks have been suppressed in the PVdF-PMMA composites. PVdF-PMMA (80:20) shows a semicrystalline nature whereas PVdF-PMMA (50:50) shows amorphous nature. Thus, by adding more PMMA in PVdF composites, the crystallinity of PVdF decreases and PVdF-PMMA (50:50) blend becomes more amorphous which enhances greater ionic diffusion causes more ionic conductivity of the polymer electrolyte membrane.

Figure 4 shows the differential scanning calorimetric (DSC) curves of PVdF, PVdF-PMMA (80-20) and PVdF-PMMA (50-50) nanofibrous membranes. In DSC curves, melting temperature $\left(T_{\mathrm{m}}\right)$ goes on decreasing from a to c. It is observed from figure that $T_{\mathrm{m}}$ for PVdF: PMMA $(100: 00)$ is $173^{\circ} \mathrm{C}$; it goes on decreasing with the incorporation of PMMA in PVdF. The value of $T_{\mathrm{m}}$ for PVdF-PMMA (80:20) and PVdF-PMMA (50:50) is 170 and $156^{\circ} \mathrm{C}$. The decrease in melting temperature is the indication of decreased crystallinity of polymer matrix in the polymeric system. It further leads to the improvement in the segmental motion of the polymeric chain and, thereby, enhances the ionic conductivity of polymer blend electrolytes. The absence of sharp glass transition and any additional peak for PVdF-PMMA blends confirm the miscibility of PMMA with PVdF in the polymer blends. The crystallinity $\left(\chi_{c} \%\right)$ of PVdF, PVdF-PMMA (80-20) and PVdF-PMMA (50-0) nanofibrous membranes was calculated from the crystalline melting heat of perfectly crystalline $\operatorname{PVdF}\left(\Delta H_{f}^{*}=105 \mathrm{~J} / \mathrm{g}\right)$, the melting enthalpy of the electrospun membranes $\left(\Delta H_{f}\right)$ in DSC curves determined from the integral area of the baseline using Eq. (1) [27] and listed in Table 1.

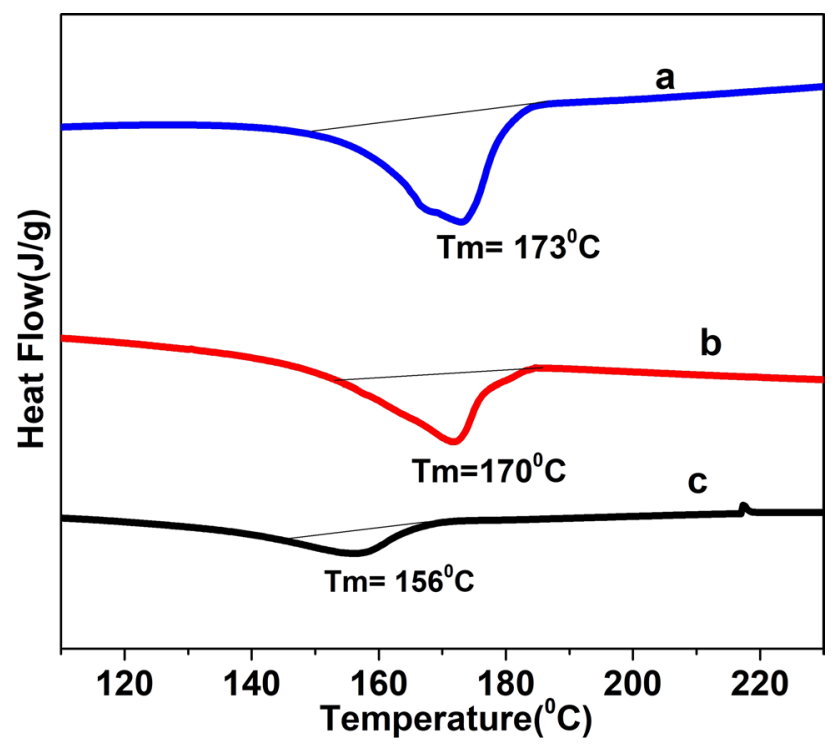

Fig. 4 DSC curves of a PVdF b PVdF-PMMA (80:20) c PVdFPMMA (50:50) nanofibrous membranes
Table 1 Melting enthalpy $\left(\Delta H_{f}\right)$, crystallinity $\left(\chi_{\mathrm{c}}\right)$, bulk resistance $\left(R_{\mathrm{b}}\right)$ and ionic conductivity $(\sigma)$ of PVdF, PVdF/PMMA (80:20) and PVdF/PMMA (50:50) nanofibrous membranes

\begin{tabular}{lllll}
\hline Polymer membranes & $\Delta H_{f}(\mathrm{~J} / \mathrm{g})$ & $\chi_{\mathrm{c}}(\%)$ & $R_{\mathrm{b}}(\Omega)$ & $\sigma(\mathrm{S} / \mathrm{cm})$ \\
\hline PVdF & 53.29 & 50.75 & 0.50 & 0.10 \\
PVdF:PMMA (80:20) & 43.84 & 41.75 & 0.29 & 0.13 \\
PVdF:PMMA (50:50) & 25.33 & 24.12 & 0.22 & 0.15 \\
\hline
\end{tabular}

$\chi_{\mathrm{c}}(\%)=\frac{\Delta H_{f}}{\Delta H_{f}^{*}} \times 100$

The evaluated crystallinity of PVdF-PMMA (50-50) membrane was found to be $24.12 \%$ as compared to $41.75 \%$ for PVdF-PMMA (80-20) and 50.75\% for pure PVdF membrane. Hence, the prepared PVdF-PMMA (50-50) membrane has the lowest crystallinity means amorphous nature as confirmed from XRD. Lowest crystallinity of PVdF-MMA (50-50) nanofibrous membrane represents the membrane suitability towards potential separator in lithium ion battery due to high electrolyte uptake and ionic conductivity which helped for more migration of lithium ions through it.

Figure 5 shows thermogravimetry (TGA) of PVdF, PVdF-PMMA (80-20) and PVdF-PMMA (50-50) nanofibrous membranes. It can be seen from the figure that the onset decomposition temperature of $\mathrm{PVdF}$ is $454{ }^{\circ} \mathrm{C}$ with a weight loss of $8 \%$. The second decomposition occurs at $510{ }^{\circ} \mathrm{C}$ with a weight loss of about $70 \%$. There are two decompositions on the TG curve of PVdF:PMMA (80:20). The first decomposition occurs at $368{ }^{\circ} \mathrm{C}$ with a weight loss of about $9 \%$ which may be due to decomposition of

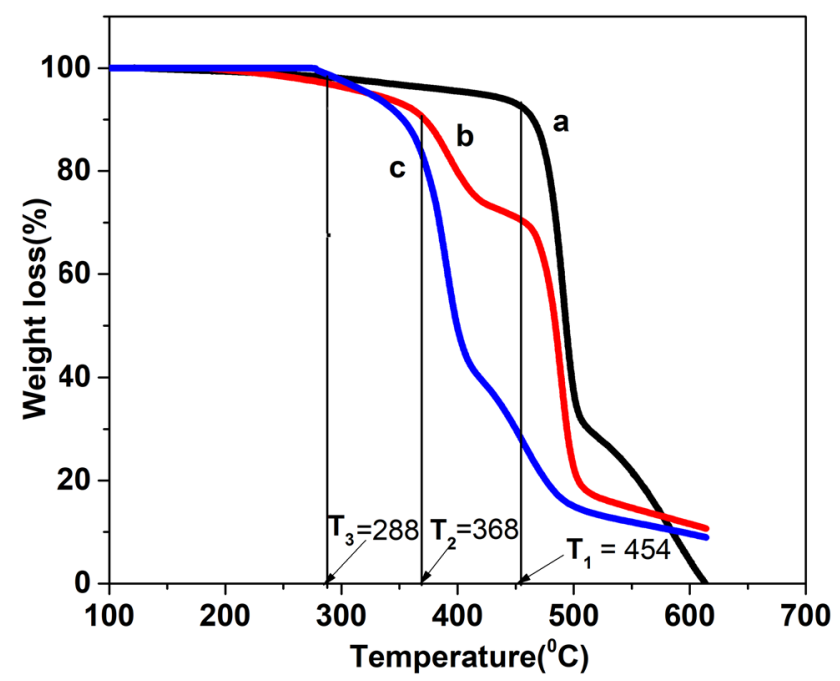

Fig. 5 Thermogravimmetry (TGA) of a PVdF, b PVdF-PMMA (80$20)$ and $\mathbf{c}$ PVdF-PMMA (50-50) nanofibrous membranes 
PMMA in the membrane. The second decomposition occurs at $430{ }^{\circ} \mathrm{C}$ with a weight loss of about $30 \%$. A small weight loss $4 \%$ is observed for PVdF: PMMA (50:50) with first decomposition temperature at $288^{\circ} \mathrm{C}$ and the second decomposition for the same composition occurs at $330{ }^{\circ} \mathrm{C}$ with a weight loss of about $30 \%$ which may be due to increase in content of PMMA in the membrane. These results indicate that the PVdF-PMMA membrane has a good thermal stability with minimum weight $\%$ loss.

Porosity of the prepared PVdF, PVdF-PMMA (80-20) and PVdF-PMMA (50-50) nanofibrous membranes was determined by $n$-butanol uptake method. Nanofibrous membranes were immersed in $n$-butanol for $2 \mathrm{~h}$. The porosity $\%$ of PVdF, PVdF-PMMA (80:20) and PVdF-PMMA (50:50) nanofibrous membrane was found to be 78,83 and $87 \%$, respectively. The high porosity was reflected to explain the high electrolyte uptake of polymer electrolytes. The electrolyte uptake behavior of the electrospun PVdF, PVdF-PMMA (80:20) and PVdF-PMMA (50:50) membrane was recorded after every $5 \mathrm{~min}$ by soaking the electrospun membranes in the liquid electrolyte $1 \mathrm{M} \mathrm{LiPF}_{6} / \mathrm{EC}: \mathrm{DMC}(1: 1 \mathrm{v} / \mathrm{v})$ solution for $30 \mathrm{~min}$. The electrolyte uptake was calculated by measuring weight of electrospun membrane before and after absorbing the electrolyte solution [27]. The PVdF, PVdF-PMMA (80:20) and PVdF-PMMA (50:50) membranes showed an electrolyte uptake of about 260, 275 and $290 \%$ within $30 \mathrm{~min}$ (Fig. 6). It is observed from the data that electrolyte uptake $\%$ increases with increasing PMMA percentage. The unique fibrous structure of the membranes induces fast liquid penetration to form the polymer electrolyte with interpenetrating polymer network within $30 \mathrm{~min}$. The higher electrolyte uptake of PVdF-PMMA (50:50) membrane could make an improvement of ionic conductivity suitable as separator

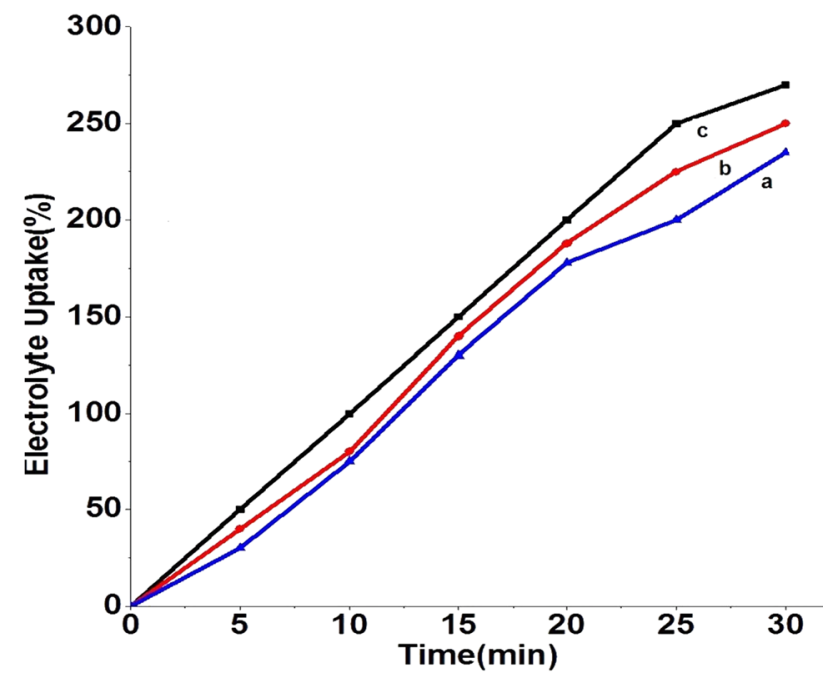

Fig. 6 Electrolyte uptake of a PVdF, b PVdF-PMMA (80:20), and c PVdF-PMMA (50:50) nanofibrous membranes for lithium ion battery. The porosity, electrolyte uptake and ionic conductivity of PVdF, PVdF-PMMA (80:20) and PVdF-PMMA (50:50) nanofibrous membranes are shown in Fig. 7. The Nyquist plot of PVdF, PVdF-PMMA (80:20) and PVdF-PMMA (50:50) nanofibrous polymer electrolyte membranes at room temperature is shown in Fig. 8. The bulk resistance $\left(R_{\mathrm{b}}\right)$ of the polymer electrolyte membranes was determined from the intercept of the extended impedance plots with the $x$ axis from the Nyquist plots. The bulk resistance was found to be decreasing with increasing \% of PMMA in PVdF. The enhancement in ionic conductivity was attributed mainly due to higher electrolyte uptake obtained by porous structure and decrease in crystallinity by adding PMMA in PVdF. Bulk resistance and ionic conductivity of PVdF, PVdF-PMMA (80:20) and PVdF-PMMA (50:50) nanofibrous polymer electrolyte membranes are listed in Table 1. The nanofibrous membranes obtained by the process of electrospinning had fully interconnected porous structures with decrease in diameter by increasing PMMA percentage in PVdF.

Battery performance was conducted by fabricating Swagelok ( $\left.\mathrm{Li} / \mathrm{PE} / \mathrm{LiFePO}_{4}\right)$ cells by placing as-fabricated nanofibrous polymer electrolyte (PE) membranes between lithium metal anode and lithium iron phosphate $\left(\mathrm{LiFePO}_{4}\right)$ cathode [8, 29]. The fabrication of test cells was carried out in a glove box. The electrochemical tests of the Li/ $\mathrm{PE} / \mathrm{LiFePO}_{4}$ cells were conducted in an automatic galvanostatic charge-discharge unit, battery cycler (Arbin BT 2000) at room temperature at the current rate of $0.1^{\circ} \mathrm{C}$. The charge-discharge process was performed between 2.6 and $4.3 \mathrm{~V}$ [30]. Figure 9 shows 1 st cycle of charge and discharge

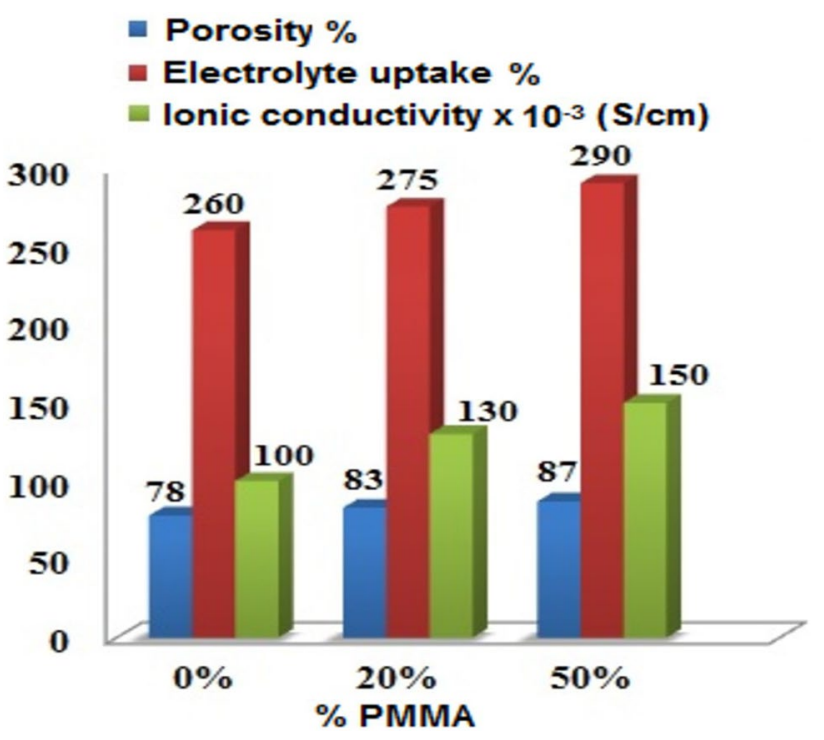

Fig. 7 Porosity, electrolyte uptake and ionic conductivity of PVdF, PVdF-PMMA (80:20) and PVdF-PMMA (50:50) nanofibrous membranes 


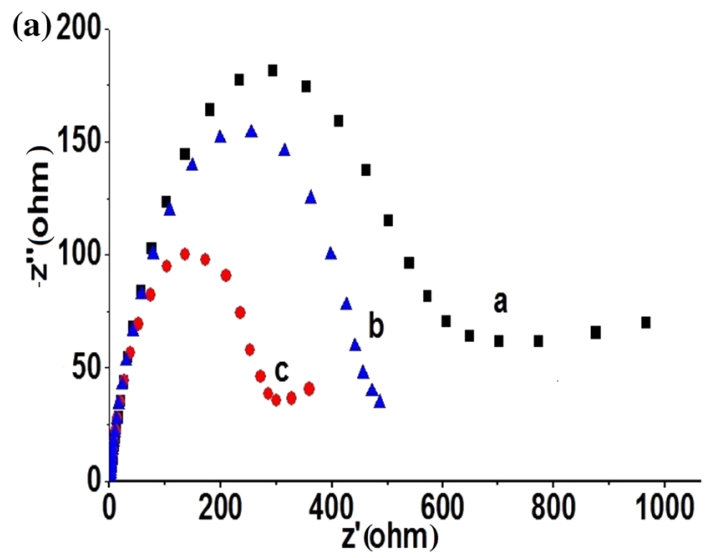

(b)

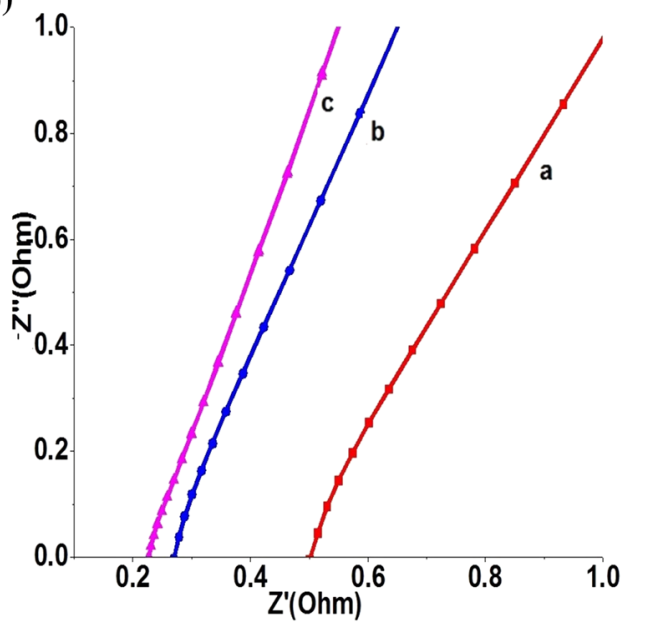

Fig. 8 Nyquist plot of a PVdF, b PVdF-PMMA (80:20) and $\mathbf{c}$ PVdFPMMA (50:50) nanofibrous polymer electrolyte membranes

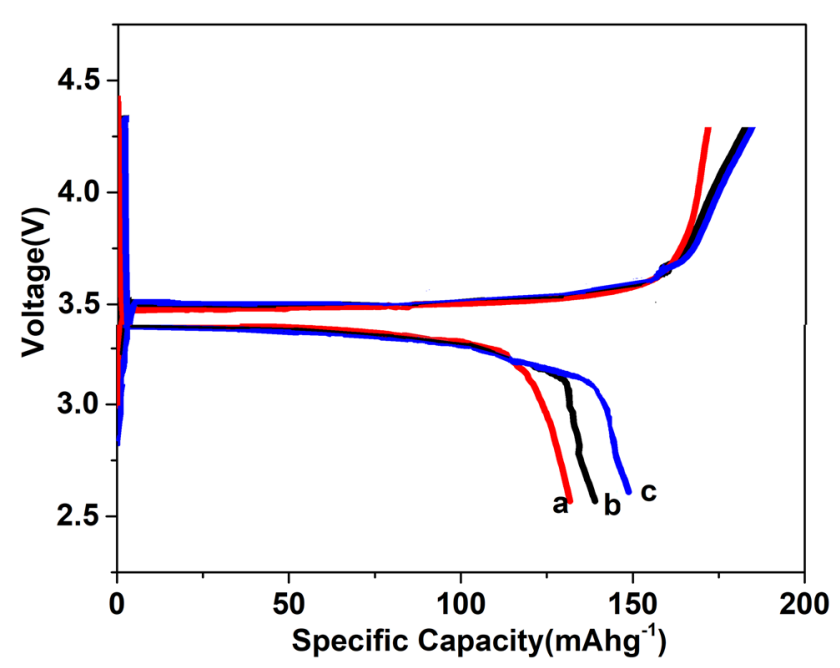

Fig. 9 1st cycle of charge and discharge curves of Swagelok cells with a PVdF, b PVdF-PMMA (80:20), and c PVdF-PMMA (50:50) nanofibrous polymer electrolyte membranes curves of fabricated Swagelok $\left(\mathrm{Li} / \mathrm{PE} / \mathrm{LiFePO}_{4}\right)$ cells. The initial discharge capacity was found to be 138.4, 144.7 and $150.3 \mathrm{mAh} / \mathrm{g}$ for separators of PVdF, PVdF/PMMA (80:20) and PVdF/PMMA (50:50) membranes, respectively. Compared with cells of different PEs, discharged capacity for the cell with PVdF-PMMA (50:50) separator was found to be relatively high cathode utilization corresponding to $88.4 \%$ of theoretical capacity. Moreover, the PVdF/PMMA (50:50) nanofibrous polymer electrolyte membrane showed a slightly higher discharge capacity than that of PVdF and PVdF/ PMMA (80:20) due to higher ionic conductivity. The cycle performance of the cells with the polymer electrolytes based on PVdF, PVdF-PMMA (80:20) and PVdF-PMMA (50:50) membranes is shown in Fig. 10. Even after 50 cycles, the discharge capacity of PVdF/PMMA (50:50) membranes was found to be $140 \mathrm{mAh} / \mathrm{g}$. This shows that $93.3 \%$ of its initial discharge capacity was retained compared to other polymer electrolytes. This indicates that the discharge capacity has a good retention even after 50 cycles. These results suggest that PVdF-PMMA (50:50) nanofibrous polymer electrolyte membrane is a potential separator for lithium ion battery.

\section{Conclusions}

PVdF-PMMA composite fibers with diameter in nanoscale membranes were successfully prepared by electrospinning. PVdF-PMMA composites membranes showed excellent electrochemical properties due to the interconnected porous structure. The increase in percentage of PMMA enhances electrolyte uptake and ionic conductivity of PVdF-PMMA composites membranes. Among PVdF-PMMA membranes

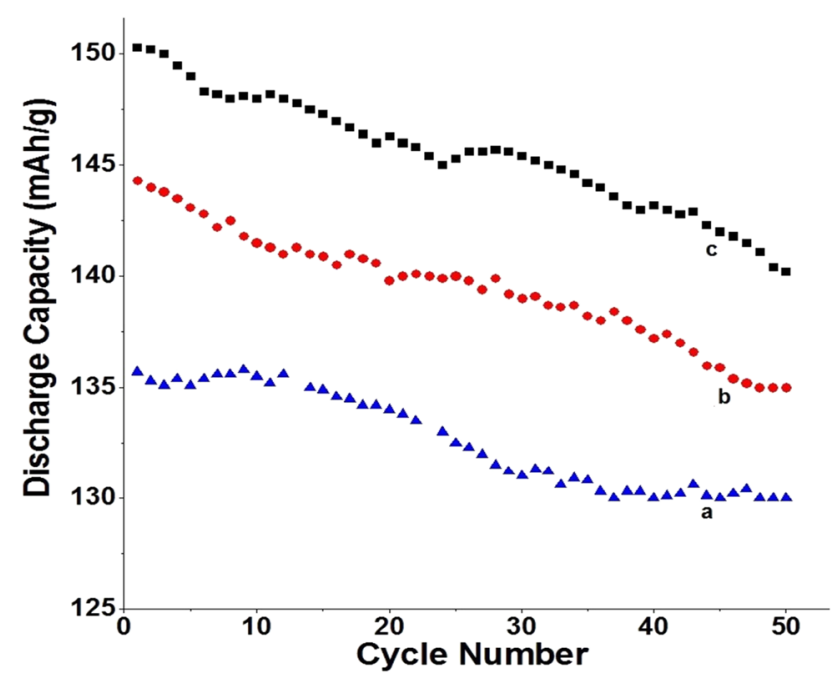

Fig. 10 Cycle performance of Swagelok cells with a PVdF, b PVdFPMMA (80:20) and c PVdF-PMMA (50:50) nanofibrous polymer electrolyte membranes 
studied, PVdF-PMMA (50:50) membrane exhibited the highest porosity, electrolyte uptake, ionic conductivity, and discharge capacity retention. These results suggested that the preparation methodology for PVdF/PMMA composites membranes by electrospinning with PVdF/PMMA (50:50) nanofibrous polymer electrolyte membrane was found to be potential and promising separator for lithium ion batteries than that of pure PVdF and PVdF-PMMA (80:20).

Acknowledgements This work was supported by the Department of Science and Technology (DST, New Delhi, India) Support under DSTFIST Program, Grant no. SR/FST/PSI-178/2012(C).

Open Access This article is distributed under the terms of the Creative Commons Attribution 4.0 International License (http://creativecommons.org/licenses/by/4.0/), which permits unrestricted use, distribution, and reproduction in any medium, provided you give appropriate credit to the original author(s) and the source, provide a link to the Creative Commons license, and indicate if changes were made.

\section{References}

1. Kim, M., Park, J.H.: Multi-scale pore generation from controlled phase inversion: application to separators for Li-ion batteries. Adv. Energy. Mater. 3, 1417-1420 (2013)

2. Zhao, Y., Wu, C., Peng, G., Chen, X., Yao, X., Bai, Y., Wu, F., Chen, S., Xu, X.: A new solid polymer electrolyte incorporating $\mathrm{Li}_{10} \mathrm{GeP}_{2} \mathrm{~S}_{12}$ into a polyethylene oxide matrix for all-solid-state lithium batteries. J. Power Source 301, 47-53 (2016)

3. Shi, Q., Yu, M., Zhou, X., Yan, Y., Wan, R.C.: Structure and performance of porous polymer electrolytes based on $\mathrm{P}(\mathrm{VDF}-$ HFP) for lithium ion batteries. J. Power Sources 103, 286-292 (2001)

4. Magistris, A.A., Quartarone, E., Mustarelli, P., Saito, Y., Kataoka, H.: PVdF based porous polymer electrolytes for lithium batteries. Solid State Ion. 152, 347-354 (2002)

5. Song, J.M., Kang, H.R., Kim, S.W., Lee, W.M., Kim, H.T.: Electrochemical characteristics of phase-separated polymer electrolyte based on poly(vinylidene fluoride-co-hexafluoropropane) and ethylene carbonate. Electrochim. Acta 48, 1339-1346 (2003)

6. Kalyana, N.T., Subramania, A.: Microstructure of PVdF-coHFP based electrolyte prepared by preferential polymer dissolution process. J. Membr. Sci. 289, 1-6 (2007)

7. Zhu, Y.S., Wang, F.X., Liu, L.L., Xiao, S.Y., Yang, Q.Y.: Composite of a nonwoven fabric with poly(vinylidene fluoride) as a gel membrane of high safety for lithium ion battery. Energy Environ. Sci. 6, 618-624 (2013)

8. Lv, R., Zhu, Y., Liu, H., Na, B., Huang, Y., Xie, X.: Poly(vinylidene fluoride)/poly(acrylonitrile) blend fibrous membranes by centrifugal spinning for high-performance lithium ion battery separators. J. Appl. Polym. Sci. 134(44515), 1-7 (2017)

9. Muthuvinayagam, M., Gopinathan, C.: Characterization of proton conducting polymer blend electrolytes based on PVdF-PVA. Polymer 68, 122-130 (2015)

10. Gentili, V., Panero, S., Reale, P., Scrosati, B.: Composite geltype polymer electrolytes for advanced, rechargeable lithium batteries. J. Power Sources 170, 185-190 (2007)

11. Raghavan, P., Zhou, X., Manuel, J., Chauhan, G., Ahn, J., Rya, H., Ahn, H.: Electrochemical performance of electrospun poly(vinylidene fluoride-co-hexaflioropropylene)-based nanocomposite polymer electrolytes incorporating ceramic fillers and room temperature ionic liquid. Electrochim. Acta 55, 1347-1354 (2010)

12. Wang, Y.J., Kim, D.: Crystallinity, morphology, mechanical properties and conductivity study of in situ formed $\mathrm{PVdF} /$ $\mathrm{LiClO}_{4} / \mathrm{TiO}_{2}$ nanocomposite polymer electrolytes. Electrochim. Acta 52, 3181-3189 (2007)

13. Pu, W.H., He, X.M., Wang, L., Jiang, C.Y., Wan, C.R.: Preparation of PVDF-HFP microporous membrane for Li-ion batteries by phase inversion. J. Membr. Sci. 272, 11-14 (2006)

14. Zhao, Y.H., Xu, Y.Y., Zhu, B.K.: Effect of amphiphilic hyperbranched-star polymer on the structure and properties of PVDF based polymer electrolytes. Solid State Ion. 180, 1517-1523 (2007)

15. Li, Z., Zhang, H., Zhang, P., Li, G.C., Wu, Y., Zhou, X.D.: Effects of the porous structure on conductivity of nanocomposite polymer electrolyte for lithium ion batteries. J. Membr. Sci. 322, 416-422 (2008)

16. Miao, R., Liu, B., Zhu, Z., Liu, Y., Li, J., Wang, X., Li, Q. PVDF-HFP-based porous polymer electrolyte membranes for lithium ion batteries. J. Power Sources 184, 420-426 (2008)

17. Liu, F., Hashim, N.A., Liu, Y., Moghareh, M.R., Li, K.: Progress in the production and modification of PVDF membranes. Membr. Sci. 375, 1-27 (2011)

18. Choi, E.S., Lee, S.Y.: Particle size-dependent, tunable porous structure of a $\mathrm{SiO}_{2} /$ poly(vinylidene fluoridehexafluoropropylene)-coated poly(ethylene terephthalate) nonwoven composite separator for a lithium-ion battery. Mater. Chem. 21, 14747-14753 (2011)

19. Kim, Y.J., Ahn, C.H., Lee, M.B., Choi, M.S.: Characteristics of electrospun $\mathrm{PVDF} / \mathrm{SiO}_{2}$ composite nanofiber membranes as polymer electrolyte. Mater. Chem. Phys. 127, 137-142 (2011)

20. Masoud, E.M.: Nano lithium aluminate filler incorporating gel lithium triflate polymer composite: preparation, characterization and application as an electrolyte in lithium ion batteries. Polym. Test. 56, 65-73 (2016)

21. Rhoo, H.J., Kim, H., Park, J., Hwang, T.: Ionic conduction in plasticized PVC/PMMA blend polymer electrolytes. Electrochim. Acta 42, 1557-1579 (1997)

22. Ma, X., Huang, X., Gao, J., Zhang, S., Deng, Z., Suo, J.: Compliant gel polymer electrolyte based on poly(methyl acrylate-coacrylonitrile)/poly(vinyl alcohol) for flexible lithium-ion batteries. Electrochim. Acta 115, 216-222 (2014)

23. Li, Z.M., Wei, J.G., Shan, F., Yang, J., Wang, X.L.: PVDF/ PMMA brushes membrane for lithium-ion rechargeable batteries prepared via pre-irradiation grafting technique. J. Polym. Sci. B Polym. Phys. 46, 751-758 (2008)

24. Idris, N., Rahman, M.M., Wang, J.Z., Liu, H.K.: Microporous gel polymer electrolytes for lithium rechargeable battery application. J. Power Sources 201, 294-300 (2012)

25. He, X., Shi, Q., Zhou, Q., Wan, C., Jiang, C.: In situ composite of nano $\mathrm{SiO}_{2}-\mathrm{P}(\mathrm{VDF}-\mathrm{HFP})$ porous polymer electrolytes for $\mathrm{Li}$ ion batteries. Electrochim. Acta 51, 1069-1075 (2005)

26. Cui, W.W., Tang, D.Y., Gong, Z.L.: Electrospun poly(vinylidene fluoride)/poly(methyl methacrylate) grafted $\mathrm{TiO}_{2}$ composite nanofibrous membrane as polymer electrolyte for lithium-ion batteries. J. Power Sources 223, 206-214 (2013)

27. Xiao, Q.Z., Li, Z.H., Gao, D.S., Zhang, H.L.: A noval sandwiched membranes as polymer electrolyte for application in lithium ion battery. J. Membr. Sci. 326, 260-264 (2009)

28. Li, X., Cao, Q., Wang, X., Jiang, S., Deng, H., Wu, N.: Preparation of poly(vinylidene fluoride)/poly(methyl methacrylate) membranes by novel electrospinning system for lithium ion batteries. J. Appl. Polym. Sci. 122, 2616-2620 (2011) 
29. Mahant, Y.P., Kondawar, S.B., Bhute, M., Nandanwar, D.V.: Electrospun poly(vinylidene fluoride)/poly(methyl methacrylate) composite nanofibers polymer electrolyte for batteries. Proced. Mater. Sci. 10, 595-602 (2015)

30. Padmaraj, O., Venkateswarlu, M., Satyanarayana, N.: Characterization and electrochemical properties of (PVdF-co-HFP) based electrospun nanocomposite fibrous polymer electrolyte membrane for lithium battery applications. Electroanalysis $\mathbf{2 6}$, 2373-2379 (2014)

31. Zhang, H., Lin, C.E., Zhou, M.Y., John, A.E., Zhu, B.K.: High thermal resistance polyimide separators prepared via soluble precursor and non-solvent induced phase separation process for lithium ion batteries. Electrochim. Acta 187, 125-133 (2016)

Publisher's Note Springer Nature remains neutral with regard to jurisdictional claims in published maps and institutional affiliations. 